\title{
Selectivity of Protein Excretion in Patients with the Nephrotic Syndrome*
}

\author{
Gary R. Joachim, $\dagger$ J. Stewart Cameron, $\$$ Melvin Schwartz, and \\ E. LOVEll BeCKer \\ (From the Departments of Medicine and Public Health, the New York Hospital-Cornell \\ Medical Center, New York, N. Y.)
}

It is generally accepted that proteinuria results from increased permeability. Although no recognizable structural abnormality has been defined to indicate a pathway of protein excretion, the permeability of the glomerular membrane, under conditions of moderate and heavy proteinuria, has been interpreted in terms of distribution of "pore size" (1-3). This concept suggests the presence of "defects" or "pores" in the glomerular membrane of such dimensions that permit the passage of these proteins into the glomerular filtrate. Factors other than size and shape that may also influence the rate of diffusion of a molecule through a membrane (4) are considered negligible. Although indirectly applicable to proteins, clearance studies in animals utilizing dextrans of varying molecular weight $(5,6)$ have demonstrated the distribution of "pore size" in the normal glomerulus within a range of molecular weights from 5,000 to 85,000 . In addition, these studies confirm the relationship between clearance of a molecule and its molecular weight.

The relationship of relative renal clearances of individual protein fractions to their corresponding molecular weight, serving as an index of glomerular permeability, has been previously applied in the clinical investigation of patients with the nephrotic syndrome (7). In this investigation

* Submitted for publication June 3, 1964; accepted August 14, 1964.

Aided by grant no. AM 05009 from the National Institute of Arthritis and Metabolic Diseases and in part by grant no. FR-47, Division of General Medical Sciences, National Institutes of Health.

† Supported by U. S. Public Health Service postdoctoral fellowship (1-F2-HE-19,861-01A1) from the National Heart Institute.

¥ Supported by postdoctoral training grant HT-5264 from the National Heart Institute. Present address: Department of Medicine, Guy's Hospital Medical School, London S.E. 1, England. this relationship has been expressed graphically as a straight line whose slope characterizes the degree of selective excretion of large or small protein molecules (Figure 1). A steep slope denotes selective filtration of small molecules, and thus suggests that the size of the glomerular "defect" is correspondingly small.

Selectivity patterns of protein excretion were determined and then compared with response to steroid therapy and renal pathology in individual patients. In addition, the patterns were correlated with blood urea nitrogen, inulin and paraaminohippuric acid clearances, total 24-hour urinary protein, and duration of disease. The results show that those patients with the nephrotic syndrome secondary to intrinsic renal disease (primary renal disease group), demonstrating a high degree of selective protein excretion before treatment, appear to respond best to steroid therapy, irrespective of the histologic findings. Furthermore, the selectivity pattern remained fairly constant for a given patient even though the total daily urinary protein excretion was fluctuating. Although no characteristic selectivity pattern was found for any given pathologic group, those patients with more advanced histologic changes in the glomeruli appeared to have the least selective type of proteinuria.

\section{Methods}

Studies were carried out in 48 patients (23 males, 25 females). Forty-five satisfied Berman and Schreiner's criteria for the nephrotic syndrome (8). Their ages ranged from 16 to 66 years with a median of 31 years, and the duration of illness ranged from 2 to 182 months with a median of 21 months. Renal biopsy was performed in 36 patients. Of the 12 patients not biopsied, the diagnosis was inferred in three who had diabetes mellitus, and in one patient in whom a unilateral renal vein thrombosis was demonstrated. Two patients with acute proliferative glomerulonephritis and one who was 
not biopsied did not have the nephrotic syndrome. In the latter case, however, the nephrotic syndrome was demonstrated 14 years before the present observation.

Pertinent data on each patient are summarized in Tables I and II. Twenty-six patients are classified under the heading, "primary renal disease," which includes the following histologic changes: pure membranous, mixed membranous-proliferative, and advanced lesions suggesting the chronic state. One patient had no change as seen by light microscopy (nil disease). The miscellaneous group comprises 22 patients: six patients with lupus nephritis, two with unilateral renal vein thrombosis, two with proliferative (poststreptococcal) glo- merulonephritis, three with diabetes mellitus, one with amyloidosis, and eight patients who were not biopsied. There were three deaths in the entire series.

The immunochemical technique has been reported by Soothill (9) and is described here in order to point out certain differences and comment on some of the difficulties encountered.

a) Collection of samples. Twenty-four-hour urine samples were collected, and heparinized plasma was obtained just after the close of the urine collection. In several instances, urine and plasma specimens were obtained during clearance studies. One drop of $1: 1,000$

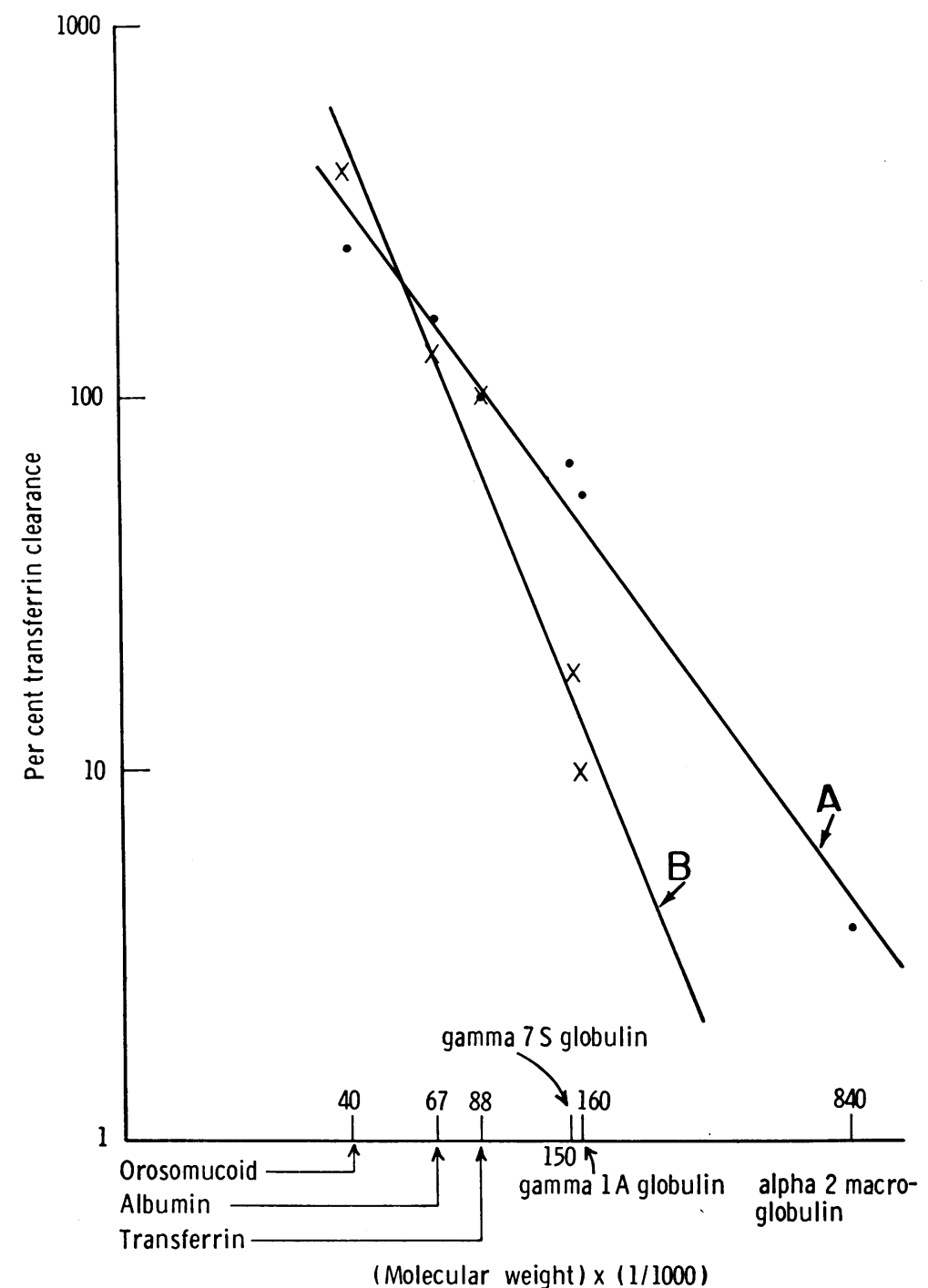

$7 / 24 / 64$

Fig. 1. Pattern of Selective protein excretion in two patients with THE NEPHROTIC SYNDROME. Line A represents the lower limit of average selectivity; line B represents the lower limit of high selectivity. 
TABLE I

Summary of clinical and pathological

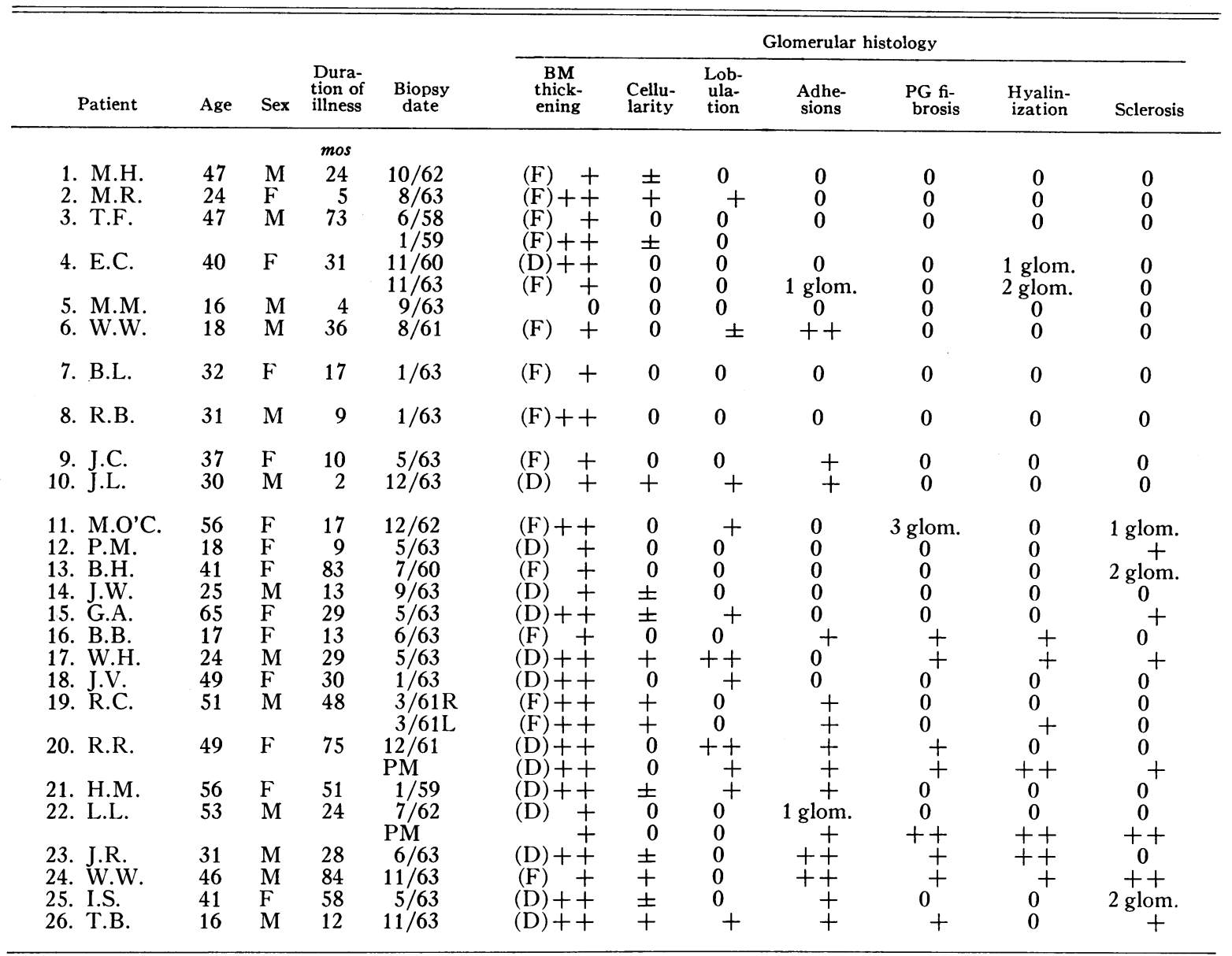

${ }^{*} \pm=$ equivocal $;+=$ minimal $;+=$ moderate $+++=$ marked. $\mathrm{R}=$ right side $; \mathrm{L}=$ left side $; \mathrm{PM}=$ postmortem; $\mathrm{BM}=$ basement membrane; $(\mathrm{F})=$ focal; $(\mathrm{D})=$ diffuse; glom. = glomerulus; $\mathrm{PG}=$ periglomerular; $\boldsymbol{\theta}=$ selectivity slope $; \mathrm{LF}=$ lost to follow-up; $U_{\text {Prot }}=$ urine protein $; \mathrm{BUN}=$ blood urea nitrogen $; \mathrm{C}_{\mathrm{Inulin}}=$ inulin clearance; $\mathrm{C}_{\mathrm{PAH}}=$ para-aminohippuric acid clearance.

$\dagger$ Slope determined before therapy.

sodium azide was added to samples of urine and plasma, and the samples were stored at $4^{\circ} \mathrm{C}$.

b) Preparation of agar plates. Two per cent agar was prepared by boiling $5 \mathrm{~g}$ of Reinagar, 1 dissolved in $250 \mathrm{ml}$ of phosphate buffer having a $\mathrm{pH}$ of 7.4 and an ionic strength of $0.15\left(201 \mathrm{ml} \mathrm{M} / 15 \mathrm{Na}_{2} \mathrm{PO}_{4}+49 \mathrm{ml}\right.$ $\mathrm{M} / 15 \mathrm{KH}_{2} \mathrm{PO}_{4}$ ), and then filtering this hot through glass wool. Eleven $\mathrm{ml}$ of agar was added to a $100-\times 15-\mathrm{mm}$ plastic Petri dish. After the agar had set, a pattern of six large holes (antigen wells, $8 \mathrm{~mm}$ diameter) surrounded by six smaller holes (antibody wells, $5 \mathrm{~mm}$ diameter) was made with a stainless steel die cutter.

c) Antisera. Goat ${ }^{2}$ or rabbit $^{1}$ antisera were obtained commercially. Rabbit antisera were prepared according to the methods of Schulze and Schwick (10). The

1 Behringwerke, A. G., Marburg-Lahn, Germany.

2 Hyland Laboratories, Los Angeles, Calif. goat antisera were prepared by using isolated and purified serum constituents as immunizing antigens. Several manipulations were required to obtain relatively pure preparations, but the yields frequently were poor (11). Both immunoelectrophoresis and a double diffusion technique were used to determine the specificity of the antigen. Dilutions and molecular weights of the proteins (12) used in this study are given in Table III.

d) Technique. Urine and plasma were suitably diluted with $0.15 \mathrm{~N} \mathrm{NaCl}$, drops being counted from Pasteur pipettes of approximately the same bore. For a urine sample containing $20 \mathrm{~g}$ of protein in $1.5 \mathrm{~L}$ (or $13.5 \mathrm{~g}$ per $\mathrm{L}$ ) and a plasma sample containing $3 \mathrm{~g}$ albumin per $100 \mathrm{ml}$, the following dilution scheme for albumin was used: urine, 1/32, 1/64; plasma, 1/64, 1/128, $1 / 256,1 / 512$. The estimated urine/plasma ratio for albumin is about 1/3. The urine/plasma ratios of other proteins were estimated in relation to that of albumin, 
TABLE I

data: primary renal disease group*

\begin{tabular}{|c|c|c|c|c|c|c|c|c|}
\hline \multirow{2}{*}{$\begin{array}{l}\text { Intersti- } \\
\text { tial infil- } \\
\text { tration }\end{array}$} & \multirow[b]{2}{*}{$\theta$} & \multirow[b]{2}{*}{ Steroids } & \multicolumn{2}{|c|}{ Response } & \multirow[b]{2}{*}{ UProt } & \multirow[b]{2}{*}{ BUN } & \multirow[b]{2}{*}{$\mathrm{C}_{\text {Itulin }}$} & \multirow[b]{2}{*}{$\mathrm{C}_{\mathrm{PAH}}$} \\
\hline & & & Grade & $\overline{\text { Class }}$ & & & & \\
\hline & & & & & $\mathrm{g} / 24 \mathrm{hrs}$ & $m g / 100 m l$ & $m l / \min$ & $m l / \min$ \\
\hline 0 & $72^{\circ} \dagger$ & Yes & 3 & & 8.13 & 20 & 127 & 670.5 \\
\hline+ & $71.3^{\circ} \dagger$ & Yes & 4 & & 11.0 & 18 & 75.2 & 272 \\
\hline 0 & $70.9^{\circ}$ & Yes & $\begin{array}{l}2 \\
1\end{array}$ & & 10.9 & 13 & & \\
\hline 0 & $70^{\circ} \dagger$ & Yes & $3,3,4$ & & 10.9 & \multirow{4}{*}{$\begin{array}{l}10 \\
15\end{array}$} & & \multirow[b]{2}{*}{203} \\
\hline 0 & $68.6^{\circ}$ & $\mathrm{x} 3$ & & & 2.25 & & 74 & \\
\hline 0 & $69.6^{\circ} \dagger$ & Yes & 4 & & 18.0 & & & \multirow[b]{2}{*}{822.8} \\
\hline \multirow[t]{2}{*}{0} & \multirow{4}{*}{$\begin{array}{l}68.5^{\circ} \dagger \\
62^{\circ} \\
67.9^{\circ} \dagger \\
70.7^{\circ} \\
67.2^{\circ}\end{array}$} & Yes & 1 & & 11.85 & & 76 & \\
\hline & & $\mathrm{x} 2$ & 1 & & $\begin{array}{l}9.6 \\
8.2\end{array}$ & 10 & & 717 \\
\hline 0 & & Yes & 3 & & $\begin{array}{l}8.2 \\
3.26\end{array}$ & 10 & 102.4 & 717 \\
\hline 0 & & $\begin{array}{c}\text { Yes } \\
(4 \text { wks })\end{array}$ & 2 & & 4.8 & 11 & & \\
\hline 0 & $66^{\circ} \mathrm{t}$ & Yes & 3 & & 10.4 & 25 & & \\
\hline+ & $65.2^{\circ} \dagger$ & Yes & 1 & & 11.0 & 20 & 80.6 & 656 \\
\hline 1 & $\begin{array}{l}60^{\circ} \\
62.3^{\circ}\end{array}$ & $\begin{array}{l}\mathrm{x} 2 \\
\mathrm{No}\end{array}$ & 1 & & 20.0 & & & \\
\hline$\stackrel{+}{+}$ & $62.3^{\circ}+$ & $\begin{array}{l}\text { No } \\
\text { Yes }\end{array}$ & & C & 32.0 & & & \\
\hline $0^{\top}$ & 60.9 & $\begin{array}{l}\text { Yes } \\
\text { Yes }\end{array}$ & $\begin{array}{l}1 \\
1\end{array}$ & & $\begin{array}{l}3.7 \\
6.33\end{array}$ & $\begin{array}{l}20 \\
13\end{array}$ & $\begin{array}{l}87.8 \\
88\end{array}$ & $\begin{array}{l}372.3 \\
456\end{array}$ \\
\hline 0 & $59^{\circ} \dagger$ & Yes & 1 & & $\begin{array}{l}0.33 \\
19.5\end{array}$ & 31 & 34.9 & 270 \\
\hline++ & $58.2^{\circ}$ & Yes & 0 & & 14.2 & 33 & 19.6 & 124.2 \\
\hline+ & $58^{\circ} \dagger$ & Yes & 1 & & 6.95 & 52 & & \\
\hline+ & $57.4^{\circ} \dagger$ & Yes & 0 & & 10.3 & 15 & 47.5 & 367 \\
\hline$+t$ & $54.9^{\circ} \dagger$ & No & & LF & 6.85 & 27 & 35 & 318.7 \\
\hline 0 & $53.2^{\circ} \dagger$ & Yes & 1 & & 12.0 & 65 & 40 & 157.3 \\
\hline $\begin{array}{l}0 \\
0\end{array}$ & $51.9^{\circ}$ & Yes & 1 & & 6.0 & 31 & 13.3 & 115.3 \\
\hline $0_{+}$ & $451^{\circ} 3^{\circ}$ & Yes & 1 & & & & & \\
\hline $0^{+}$ & $\begin{array}{l}510^{\circ} \dagger \\
50.8^{\circ}\end{array}$ & $\begin{array}{l}\text { Yes } \\
\text { Yes }\end{array}$ & $\begin{array}{l}1 \\
0\end{array}$ & & 10.0 & $\begin{array}{l}60 \\
30\end{array}$ & 25.5 & \\
\hline+ & $50.7^{\circ}$ & No & & & 100 & & 258 & \\
\hline $0^{+}$ & $49.5^{\circ}$ & No & & D & $\begin{array}{l}10.0 \\
13.0\end{array}$ & $\begin{array}{l}51 \\
35\end{array}$ & 25.8 & 410.3 \\
\hline 0 & $48^{\circ} \dagger$ & Yes & 1 & & 9.3 & 10 & & \\
\hline+ & $45^{\circ} \dagger$ & Yes & 0 & & 15.0 & 58 & 36 & 137.5 \\
\hline
\end{tabular}

and urine and plasma dilutions were prepared accordingly. Diluted samples of urine were placed in the large wells $A$ and $B$ (Figure 2) and diluted plasma samples in the other four large wells C, D, E, and F. Serial dilutions of antibody were placed in the small wells in an alternating clockwise-counter-clockwise fashion.

The plates were covered and left at room temperature for 24 hours. Lines of precipitation were noted against a dark background. If the urine samples did not fall within the range of plasma dilutions, the procedure was repeated with more suitable dilutions. The plates were filled with $5 \%$ formalin, left standing for 4 hours, then washed for 3 days with frequent changes of $0.15 \mathrm{~N}$ $\mathrm{NaCl}$. They were stained for 15 minutes with amido black 10B (0.5 g amido black $10 \mathrm{~B}$ and $5.0 \mathrm{~g}$ mercuric chloride dissolved in $100 \mathrm{ml}$ of $10 \%$ acetic acid). The plates were destained with repeated washes of $5 \%$ acetic acid until a clear, light background was obtained.
Drying the plates at room temperature resulted in a thin film, and this was used for comparison of precipitin lines.

e) Estimation of urine/plasma protein ratios. The plates and the dried films were read by visually matching hexagonal (or semihexagonal) precipitin lines of the urine with those of the plasma. Distance of the line from the antibody well as well as clarity and density of the line were the reference points. The use of a viewer and millimeter rule facilitated more accurate estimation. The result was expressed as a concentration ratio (urine/plasma). If a precipitin pattern appeared to fall between two plasma dilutions, the result was interpolated arithmetically, i.e., between $1 / 32$ and $1 / 64$, a dilution would be read as $1 / 36,1 / 40,1 / 44$, $1 / 48,1 / 52$, or $1 / 56$.

In some instances spurs or reactions of partial identity were noted between precipitin bands. Usually this was 
TABLE II

Summary of clinical data

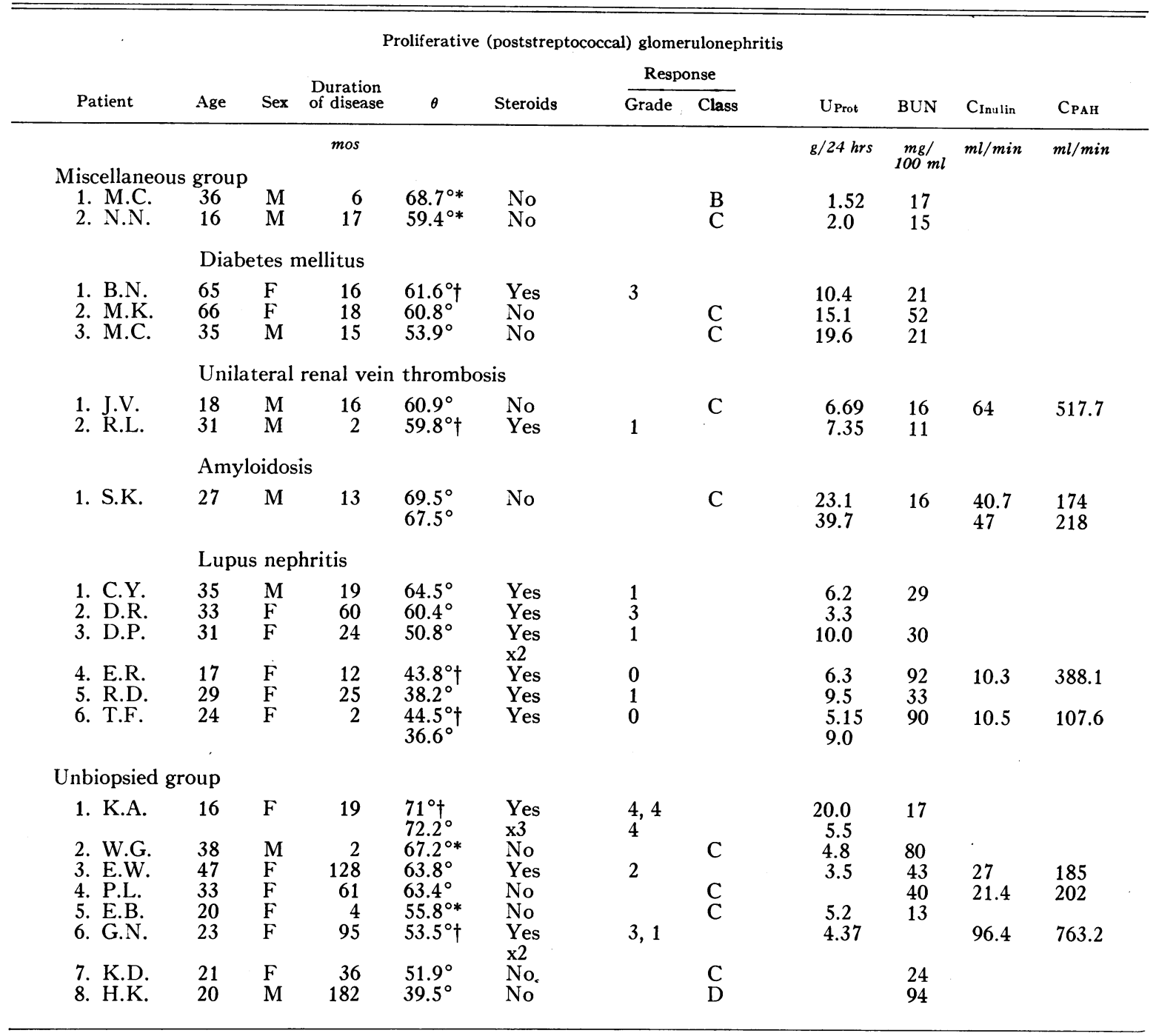

* Selectivity slope determined early in course of disease.

† Selectivity slope determined before steroid therapy.

TABLE III

Antibody dilutions

\begin{tabular}{|c|c|c|c|c|c|c|c|}
\hline \multirow[b]{2}{*}{ Antibody to } & \multirow{2}{*}{$\begin{array}{c}\text { Approximate } \\
\text { molecular } \\
\text { weight }\end{array}$} & \multicolumn{6}{|c|}{ Dilutions } \\
\hline & & 1 & 2 & 3 & 4 & 5 & 6 \\
\hline $\begin{array}{l}\text { Orosomucoid } \\
\text { Albumin } \\
\text { Transferrin } \\
7 \text { S gamma globulin } \\
\text { Gamma }_{1 \mathrm{~A}} \text { globulin } \\
\text { Alpha }_{2} \text { macroglobulin } \\
\text { Beta }_{2} \text { macroglobulin } \\
\text { Beta lipoprotein }\end{array}$ & $\begin{array}{r}40,000 \\
67,000 \\
88,000 \\
150,000 \\
160,000 \\
840,000 \\
890,000 \\
2,500,000\end{array}$ & $\begin{array}{l}1 / 1 \\
1 / 1 \\
1 / 1 \\
1 / 1 \\
1 / 1 \\
1 / 1 \\
1 / 1 \\
1 / 1\end{array}$ & $\begin{array}{l}1 / 2 \\
1 / 2 \\
1 / 2 \\
1 / 2 \\
1 / 2 \\
1 / 2 \\
1 / 2 \\
1 / 2\end{array}$ & $\begin{array}{l}1 / 4 \\
1 / 4 \\
1 / 3 \\
1 / 4 \\
1 / 3 \\
1 / 3 \\
1 / 3 \\
1 / 3\end{array}$ & $\begin{array}{l}1 / 8 \\
1 / 8 \\
1 / 4 \\
1 / 6 \\
1 / 4 \\
1 / 4 \\
1 / 4 \\
1 / 4\end{array}$ & $\begin{array}{l}1 / 12 \\
1 / 16 \\
1 / 5 \\
1 / 8 \\
1 / 6 \\
1 / 6 \\
1 / 6 \\
1 / 6\end{array}$ & $\begin{array}{l}1 / 16 \\
1 / 32 \\
1 / 6 \\
1 / 10 \\
1 / 8 \\
1 / 8 \\
1 / 10 \\
1 / 8\end{array}$ \\
\hline
\end{tabular}


not seen with albumin, transferrin, $\gamma_{1 \mathrm{~A}}$ globulin, and $\gamma_{7 \mathrm{~s}}$ globulin antisera. More than one precipitin line was observed with orosomucoid and beta lipoprotein, and occasionally with $\alpha_{2}$ macroglobulin antisera. Dilution of both antigen and antibody somewhat eliminates this reaction when nonspecific antibodies are present in the testing antisera (13), and the strongest band was used.

Sometimes splitting or reduplication of the precipitin line was noted, indicating an excess of antigen or antibody. The determination was repeated using the same antisera with more appropriate antigen dilutions.

It is apparent that different lots of antisera give different results when measuring the same antigen. The same lot was used for a series of determinations, and its specificity was checked by immunoelectrophoresis against human serum.

f) Determination of the slope. From the urine/plasma ratios of five or more protein fractions, net protein clearances were determined and expressed as the percentage of transferrin clearance: e.g., $\left(\mathrm{U}_{\mathrm{Alb}} \mathrm{V} / \mathrm{P}_{\mathrm{Alb}}\right) \div$ $\left(\mathrm{U}_{\text {Trans }} \mathrm{V} / \mathrm{P}_{\text {Trans }}\right) \times 100$, where $\mathrm{U}=$ urinary concentration of the protein; $\mathrm{P}=$ plasma concentration of the protein; and $\mathrm{V}=$ urine flow in milliliters per minute. Because the urine flow is the same for the two clearances, the $\mathrm{V}$ term cancels out of the relative clearance expression leaving $U_{1} / P_{1}$. Since the technique for the determination of transferrin (Trans) has a slightly lower variance than that of albumin (Alb), transferrin clearance is used as the reference in this relationship (14). These percentage values are plotted as ordinates against respective molecular weights on a $\log -\log$ graph. Such plots are generally linear (Figure 1). Among the different plots investigated were arithmetic plot of clearance vs. molecular weight, $\log$ clearance vs. molecular weight, $\log$ molecular weight vs. clearance, etc. No one of these empirical graphs produced the consistent linearity of the $\log -\log$ plot. A straight line was estimated by the method of least squares, and the slope $(\mathrm{K})$ was determined. The angle $(\theta)$ is derived from $\mathrm{K}$, the tangent of $\theta$, and expresses degree of selectivity. Protein clearances, expressed as a percentage of inulin clearance, $\mathrm{C}_{\mathrm{Alb}} / \mathrm{C}_{\text {Inul In }}, \mathrm{C}_{\mathrm{Trans}} / \mathrm{C}_{\text {Inul In }}$, etc., were similarly plotted. "The slopes of these lines were nearly identical with those obtained using the transferrin percentages.

g) Analyses. Sixty-five determinations of selectivity were performed on 48 patients. The mean slope (expressed here as $\theta$ ) was $58.6^{\circ}$, the median was $60.1^{\circ}$, the standard deviation was $9.0^{\circ}$, the coefficient of variation was $15.35 \%$, and the standard error of the mean was $1.3 \%$.

The selectivity measurements defined as $\theta$, or alternatively as $\mathrm{K}$ (tangent $\theta$ ), were plotted against a probit scale (Figure 3 ). This scale is essentially a scale in units of standard deviation and has found its most routine application in dose response data, and it provides a convenient method of examining data for consistency with a normal distribution. The linearity of the plot was taken to indicate that the distribution of selectivity slopes for the patient group studied was con-

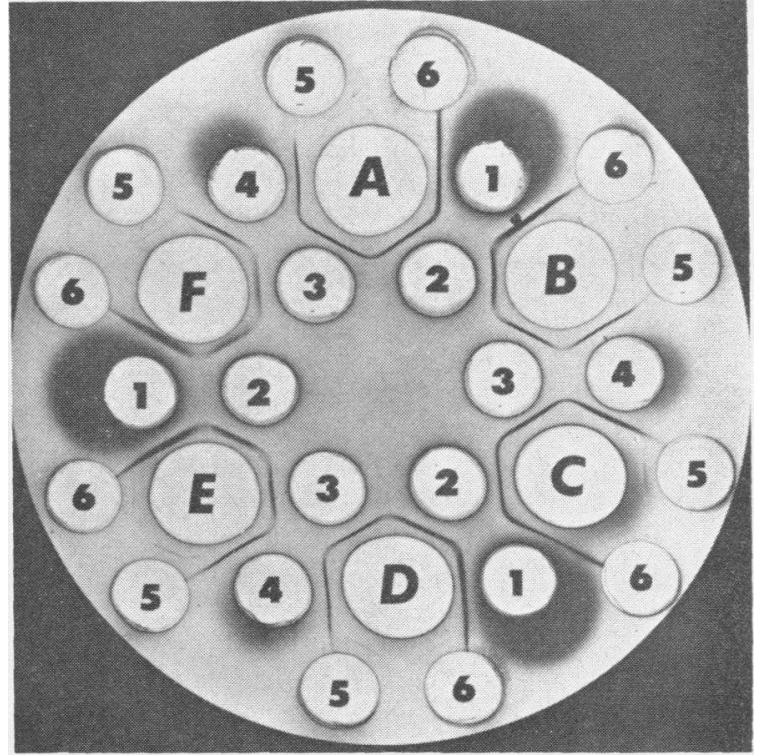

Fig. 2. Stained AND DRIED AGAR FILM SHOWING PRECIPITIN LINES OBTAINED BY THE IMML NODIFFCSION TECHNIQCE. The lettered wells $A$ and $B$ contain different dilutions of urine; C, D, E, and F contain different dilutions of plasma. The numbered wells contain different dilutions of specific antibody. The precipitin lines around $\mathrm{A}$ and $\mathrm{C}$ are comparable as are those lines around $\mathrm{B}$ and $\mathrm{D}$.

sistent with a normal or bell-shaped distribution. A1though it would be difficult to set absolute limits with the small number of individuals reported in this study, the roughly bell-shaped curve of the population allows one to set up standards of selectivity in terms of the patterns of protein excretion. The units of $\frac{1}{2} \mathrm{SD}$ demarcated subjects into four groups (Table IV).

h) Chemical analyses. Total urinary protein was determined by a modification of the method of Hiller, McIntosh, and Van Slyke (15), in which Pro-Sol ${ }^{3}$ was used as the standard protein solution. Urine and plasma alkali-stable inulin was determined by the method of Walser, Davidson, and Orloff (16), and urine and plasma para-aminohippurate was determined by the method of Smith and associates (17).

\section{Results}

Effects of protein denaturation and loss. Patte, Baldassaire, and Loret (18) reported no differences in immunochemical studies on urine stored at $4^{\circ} \mathrm{C}$ for 8 days without preservative. Berggård (19) found no alteration in the serologic precipitation pattern of urinary gamma globulin after the urine had been stored for 10 days at room

\footnotetext{
${ }^{3}$ Pro-Sol was obtained from the Standard Scientific
} Supply Corp., New York, N. Y. 


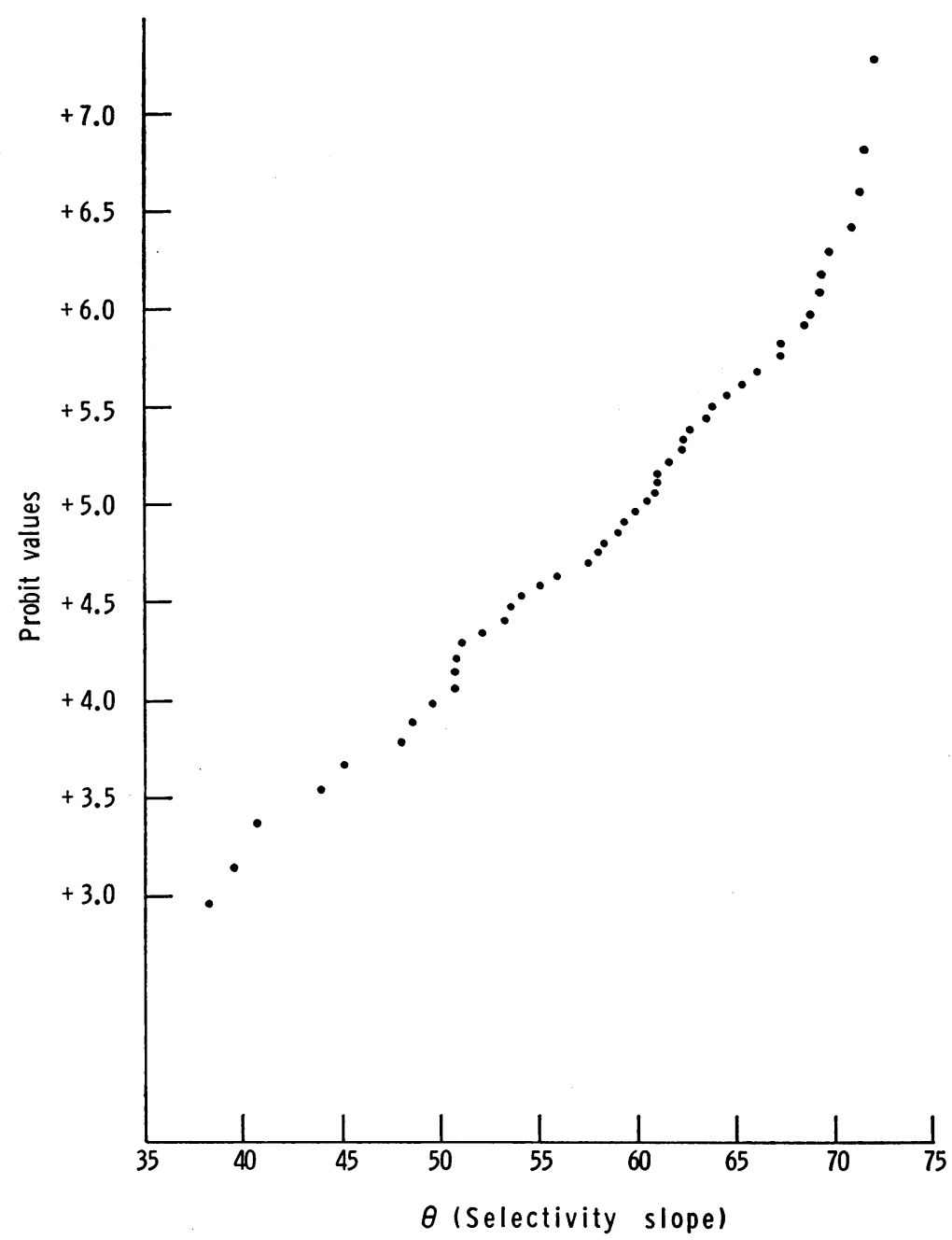

Fig. 3. Selectivity Slopes of the entire group of patients plotted AGAINST A PROBIT SCALE.

temperature. In this study identical results were obtained from a fresh urine specimen, and the same specimen was kept at $4^{\circ} \mathrm{C}$ for 2 weeks. Apparently many proteins retain immunologic specificity despite denaturation from enzymatic

TABLE IV

Grouping of patients according to selectivity types

\begin{tabular}{lc}
\hline \hline $\begin{array}{c}\text { Selectivity type } \\
\text { of proteinuria }\end{array}$ & $\theta$ (Average $\left.\theta=58.6^{\circ}, 1 \mathrm{SD}=9.0^{\circ}\right)$ \\
\hline Low & Below $54^{\circ}<$ (average $\left.\theta-\frac{1}{2} \mathrm{SD}\right)$ \\
Average & $54^{\circ}-63^{\circ}$ (average $\left.\theta \pm \frac{1}{2} \mathrm{SD}\right)$ \\
Intermediate & $63.1^{\circ}-67^{\circ}>$ (average $\left.\theta+\frac{1}{2} \mathrm{SD}\right)$ \\
& $<$ (average $\theta+1 \mathrm{SD})$ \\
High & Greater than $67^{\circ}$ (average $\left.\theta+1 \mathrm{SD}\right)$ \\
\hline
\end{tabular}

activity or other processes. Boiling urine until the protein precipitated did not alter the immunologic reactivity of the protein fractions measured.

In some cases urine samples were dialyzed against distilled water at room temperature in tubing prepared from Visking membranes, then pervaporated to obtain greater concentration. This treatment caused no protein loss as determined immunochemically on pervaporated or lyophilized specimens of the dialyzate.

Reproducibility of results. Since this method has many variables that could add to the errors of determination, and since it depends upon human judgment, a double blind study was performed to test the reproducibility of results. Five urine 
TABLE V

Results of double blind study*

\begin{tabular}{|c|c|c|c|c|c|c|c|}
\hline \multirow[b]{2}{*}{ Patient } & \multirow{2}{*}{$\begin{array}{l}\text { Selectivity } \\
\text { slope }\end{array}$} & \multicolumn{6}{|c|}{$\mathrm{U} / \mathrm{P}$ ratios } \\
\hline & & Oroso & Alb & Trans & $7 \mathrm{~S}$ & $\gamma_{1 \mathrm{~A}}$ & $\alpha_{2 \mathrm{M}}$ \\
\hline 1. $\underset{\mathrm{B}}{\mathrm{A}}$ & $\begin{array}{l}71^{\circ} 07^{\prime} \\
71^{\circ} 03^{\prime}\end{array}$ & $\begin{array}{l}1: 24 \\
1: 20\end{array}$ & $\begin{array}{l}1: 128 \\
1: 200\end{array}$ & $\begin{array}{l}1: 128 \\
1: 200\end{array}$ & $\begin{array}{l}1: 512 \\
1: 512\end{array}$ & $\begin{array}{l}0 \dagger \\
0\end{array}$ & $\begin{array}{l}0 \\
0\end{array}$ \\
\hline 2. $\underset{\mathrm{B}}{\mathrm{A}}$ & $\begin{array}{l}75^{\circ} 44^{\prime} \\
69^{\circ} 39^{\prime}\end{array}$ & $\begin{array}{l}1: 1.25 \\
1: 1\end{array}$ & $\begin{array}{l}1: 3.9 \\
1: 3.5\end{array}$ & $\begin{array}{l}1: 3 \\
1: 4\end{array}$ & $\begin{array}{l}1: 150 \\
1: 32\end{array}$ & $\begin{array}{l}1: 32 \\
1: 40\end{array}$ & $\begin{array}{l}0 \\
0\end{array}$ \\
\hline 3. $\underset{\mathrm{B}}{\mathrm{A}}$ & $\begin{array}{l}67^{\circ} 33^{\prime} \\
71^{\circ} 44^{\prime}\end{array}$ & $\begin{array}{l}5.33 \\
8.00\end{array}$ & $\begin{array}{l}2.67 \\
4.00\end{array}$ & $\begin{array}{l}2.00 \\
2.00\end{array}$ & $\begin{array}{l}1: 2 \\
1: 2\end{array}$ & $\begin{array}{l}1: 7 \\
1: 8\end{array}$ & $1: 256$ \\
\hline 4. $\stackrel{\mathrm{A}}{\mathrm{B}}$ & $\begin{array}{l}56^{\circ} 07^{\prime} \\
62^{\circ} 04^{\prime}\end{array}$ & $\begin{array}{l}1.45 \\
2.00\end{array}$ & $\begin{array}{l}1: 8 \\
1: 8\end{array}$ & $\begin{array}{l}1: 5 \\
1: 4\end{array}$ & $\begin{array}{l}1: 1.2 \\
1: 1.2\end{array}$ & $\begin{array}{l}1: 3 \\
1: 5\end{array}$ & $\begin{array}{l}1: 150 \\
1: 300\end{array}$ \\
\hline 5. $\underset{\mathrm{B}}{\mathrm{A}}$ & $\begin{array}{l}67^{\circ} 04^{\prime} \\
65^{\circ} 16^{\prime}\end{array}$ & $\begin{array}{l}1: 1.5 \\
1: 1.5\end{array}$ & $\begin{array}{l}1: 3 \\
1: 2\end{array}$ & $\begin{array}{l}1: 2 \\
1: 2\end{array}$ & $\begin{array}{l}1: 6 \\
1: 8\end{array}$ & $\begin{array}{l}1: 20 \\
1: 12\end{array}$ & $\begin{array}{l}0 \\
0\end{array}$ \\
\hline
\end{tabular}

${ }^{*} \mathrm{U} / \mathrm{P}=$ urine to plasma, Oroso $=$ orosomucoid, $\mathrm{Alb}=$ albumin, and Trans $=$ transferrin.

$\dagger 0=$ undetected at a $1: 1$ dilution.

and plasma specimens were given to one individual who divided each set into two pairs and coded them. The pairs were distributed randomly to two technicians who performed the entire procedure, determining urine/plasma ratios and the selectivity slopes independently. Results are given in Table $\mathrm{V}$. The degree of reproducibility was good. The results of technician A and technician B did not differ significantly.

Comparison of selectivity type with steroid response. The criteria for response to steroid therapy are given in Table VI. All patients receiv. ing steroids were treated initially with $60 \mathrm{mg}$ prednisone or prednisolone per 24 hours for approximately 4 weeks. The dose was then tapered to a maintenance level of $20 \mathrm{mg}$ or more and given over a prolonged period, usually 1 year. Duration of follow-up ranged from 2 to 182 months with a median of 13 months. One patient was lost to follow-up.

In a prospective analysis (Figure 4), selectivity types were determined before therapy or early in the course of disease in 29 patients. Twenty-one were treated with steroids. Of the eight with a grade 3 or 4 response following steroid therapy, six had high selectivity types of proteinuria, and one had an intermediate selectivity slope. The one patient (B. N.) who had diabetes mellitus and was treated with a short course of steroids had a grade 3 response despite a slope equivalent to the average selectivity type. Of 13 patients who did not respond to steroid therapy, six had low, five had average, one had intermediate, and one patient, mentioned previously, had high selectivity types of proteinuria. In the entire series, six patients had a grade 0 response to steroids. Of these, four had low selectivity types of proteinuria (two with primary

TABLE VI

Criteria for response

To steroid therapy

Grade 4 (excellent): Complete clinical remission with normal blood chemistries and urine analysis

Grade 3 (good): Return to normal of biochemical alterations but residual proteinuria

Grade 2 (fair): Diuresis but no significant changes in blood chemistries or urine analysis

Grade 1 (poor): No alteration in the disease process

Grade 0 (worse): Exacerbation of the disease under steroid therapy, as judged by blood pressure, blood chemistries, and urine examination

In the untreated patient

Class A : Spontaneous remission

Class B : Improvement in renal function and/or return to normal of biochemical alterations, but with residual proteinuria

Class C: $\quad$ Unchanged clinical condition as judged by blood chemistries and urine analysis

Class D: $\quad$ Progressive deterioration 


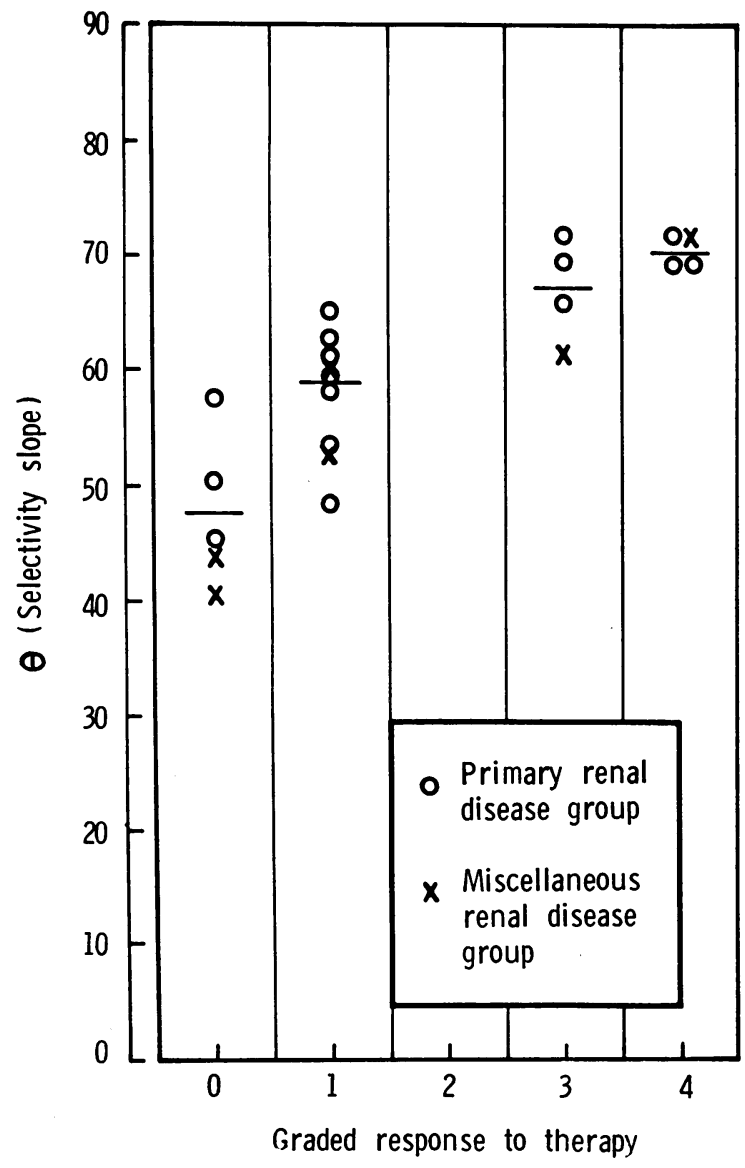

Fig. 4. Analysis of 22 patients treated with STEROIDS AFTER THE DETERMINATION OF THE SELECTIVITY SLOPE. The horizontal line indicates the average selectivity slope for each group.

renal disease, two with lupus nephritis), and two had an average slope.

The group comprising those patients with secondary forms of the nephrotic syndrome is small; therefore, it is uncertain whether the measurement of the selectivity type of proteinuria will be of value as a possible guide to steroid therapy.

In summary, in patients with primary renal disease and the nephrotic syndrome, there appears to be a direct relationship between the initial clinical response to steroid therapy and the degree of selective protein excretion. Of eight patients treated, six who had high selectivity types recorded before therapy responded well to steroids. The one patient who had a high selectivity type of proteinuria but did not respond to steroids was found 15 months later to have a slope equivalent to the average selectivity type. Those patients with low selectivity types of proteinuria did not respond to therapy.

Comparison of selectivity type with total protein excretion. There appears to be no correlation between the degree of selective protein excretion and the total daily amount of protein excreted $\left(r_{40}=+0.03, p>0.1\right)$. Some patients who excreted more than $15 \mathrm{~g}$ of protein in 24 hours were found to have high selectivity types. Other patients, whose total protein excretion was less than $5 \mathrm{~g}$ in 24 hours, had low selectivity slopes.

Table VII summarizes those patients in whom selectivity types were repeated and correlated with varying total protein excretion observed during response to therapy. In three patients who did not respond to steroids, the selectivity slope was less but not less than $1 \mathrm{SD}$ from the original slope. Two of these patients had a grade 0 response. Four patients who did respond to therapy had relatively constant selectivity types as total protein excretion decreased. Squire, Hardwicke, and Soothill (14) have commented that when proteinuria persists, the degree of selectivity usually remains relatively constant over many months. All but one patient (M. R.) having repeated determinations of selectivity types over several months displayed no change greater than 1 SD from the average.

Comparison of selectivity type with glomerular histology. Blainey, Brewer, Hardwicke, and Soothill (7), using the same technique employed here, reported that patients with minimal glomerular pathology had the highest selectivity type of proteinuria, those with membranous glomerulonephritis displayed the least selective type, and those with proliferative glomerulonephritis had intermediate selectivity. Although each group in our study is small, those patients with membranous glomerulonephritis displayed the highest selectivity type of proteinuria. Those patients having lesions of chronic glomerulonephritis tended to have a low selectivity type of proteinuria.

In summary, those patients within the primary renal disease group may have high selectivity types of proteinuria irrespective of the degree of glomerular alteration in the acute or subacute state. Those displaying chronic changes tend to have low or average selectivity types. A comparison of the histologic features of the nephrotic syndrome, both primary and secondary, with selectivity patterns 
TABLE VII

Comparison of the selectivity slope with fluctuation in urinary protein

\begin{tabular}{|c|c|c|c|c|c|c|}
\hline Patient & Date & $\begin{array}{l}\text { Selectivity } \\
\text { slope }(\theta)\end{array}$ & $C_{\text {Trans }}$ & $\mathrm{C} ; \mathrm{s}$ & $\begin{array}{l}\text { Total } \\
\text { urine } \\
\text { protein }\end{array}$ & Comment \\
\hline 1. M.R. & $\begin{array}{r}9 / 6 / 63 \\
9 / 12 / 63 \\
9 / 25 / 63 \\
10 / 20 / 63\end{array}$ & $\begin{array}{l}66.0^{\circ} \\
71.0^{\circ} \\
72.7^{\circ} \\
75.6^{\circ}\end{array}$ & $\begin{array}{c}m \mathrm{ml} \text { minute } \\
1.150 \\
0.005 \\
0.125 \\
0.370\end{array}$ & $\begin{array}{c}m l / m i n u t e \\
0.380 \\
0.001 \\
0.015 \\
0.040\end{array}$ & $\begin{array}{r}g / 24 h r s \\
15.20 \\
1.60 \\
2.50 \\
11.40\end{array}$ & $\begin{array}{l}\text { Before treatment } \\
\text { Receiving steroids } \\
\text { Receiving steroids } \\
\text { Receiving steroids }\end{array}$ \\
\hline 2. W.W. & $\begin{array}{r}10 / 62 \\
1 / 64\end{array}$ & $\begin{array}{l}68.5^{\circ} \\
62.0^{\circ}\end{array}$ & $\begin{array}{l}0.690 \\
0.540\end{array}$ & $\begin{array}{l}0.086 \\
0.114\end{array}$ & $\begin{array}{r}11.85 \\
9.60\end{array}$ & $\begin{array}{l}\text { Before treatment } \\
\text { Receiving steroids }\end{array}$ \\
\hline 3. E.C. & $\begin{array}{r}12 / 17 / 62 \\
3 / 14 / 63\end{array}$ & $\begin{array}{l}70.0^{\circ} \\
68.6^{\circ}\end{array}$ & $\begin{array}{l}0.291 \\
0.068\end{array}$ & $\begin{array}{l}0.073 \\
0.013\end{array}$ & $\begin{array}{r}10.90 \\
2.25\end{array}$ & $\begin{array}{l}\text { Before treatment } \\
\text { Receiving steroids }\end{array}$ \\
\hline 4. J.L. & $\begin{array}{r}12 / 29 / 63 \\
1 / 16 / 64\end{array}$ & $\begin{array}{l}65.2^{\circ} \\
60.0^{\circ}\end{array}$ & $\begin{array}{l}0.932 \\
1.040\end{array}$ & $\begin{array}{l}0.077 \\
0.500\end{array}$ & $\begin{array}{l}10.90 \\
20.30\end{array}$ & $\begin{array}{l}\text { Before treatment } \\
\text { Receiving steroids }\end{array}$ \\
\hline 5. K.A. & $\begin{array}{l}1 / 6 / 64 \\
1 / 11 / 64\end{array}$ & $\begin{array}{l}71.0^{\circ} \\
72.2^{\circ}\end{array}$ & $\begin{array}{l}1.470 \\
0.160\end{array}$ & $\begin{array}{l}0.090 \\
0.014\end{array}$ & $\begin{array}{r}17.90 \\
5.50\end{array}$ & $\begin{array}{l}\text { Before treatment } \\
\text { Receiving steroids }\end{array}$ \\
\hline 6. T.F. & $\begin{array}{l}7 / 16 / 63 \\
8 / 17 / 63\end{array}$ & $\begin{array}{l}44.5^{\circ} \\
36.6^{\circ}\end{array}$ & $\begin{array}{l}0.280 \\
0.130\end{array}$ & $\begin{array}{l}0.047 \\
0.063\end{array}$ & $\begin{array}{l}5.70 \\
9.00\end{array}$ & $\begin{array}{l}\text { Before treatment } \\
\text { Receiving steroids }\end{array}$ \\
\hline 7. S.K. & $\begin{array}{l}4 / 3 / 63 \\
4 / 23 / 63\end{array}$ & $\begin{array}{l}69.0^{\circ} \\
67.5^{\circ}\end{array}$ & $\begin{array}{l}3.100 \\
1.600\end{array}$ & $\begin{array}{l}0.410 \\
0.300\end{array}$ & $\begin{array}{l}41.80 \\
37.70\end{array}$ & $\begin{array}{l}\text { No steroids } \\
\text { No steroids }\end{array}$ \\
\hline 8. B.L. & $\begin{array}{r}12 / 62 \\
2 / 64\end{array}$ & $\begin{array}{l}67.9^{\circ} \\
70.7^{\circ}\end{array}$ & $\begin{array}{l}0.090 \\
0.080\end{array}$ & $\begin{array}{l}0.030 \\
0.018\end{array}$ & $\begin{array}{l}8.20 \\
3.26\end{array}$ & $\begin{array}{l}\text { Before treatment } \\
\text { Receiving steroids }\end{array}$ \\
\hline
\end{tabular}

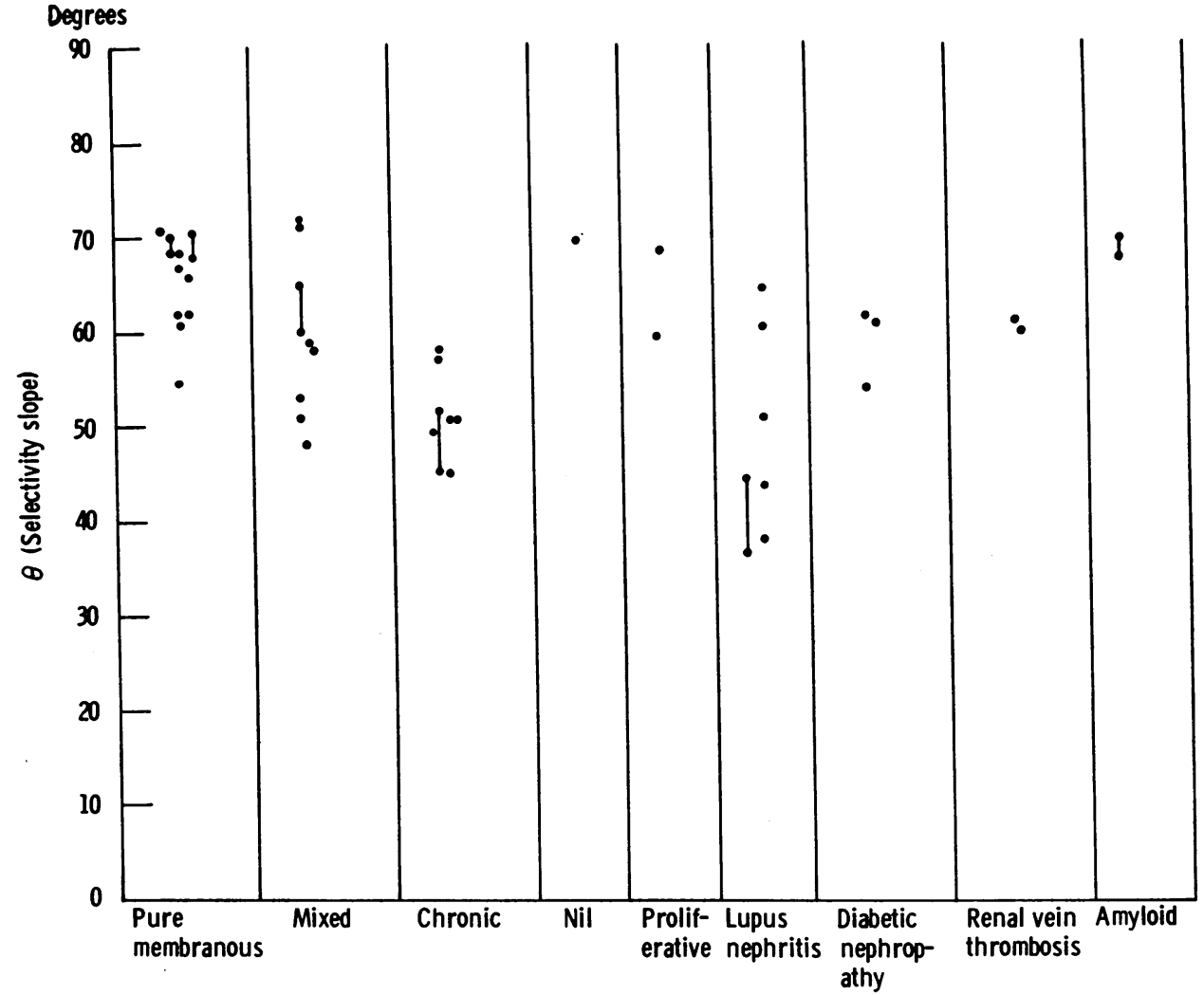

Fig. 5. Comparison of individual Selectivity SLOPES With histological features of the NEPHROTIC SYNDROME. Connected points represent determinations on the same individual. 


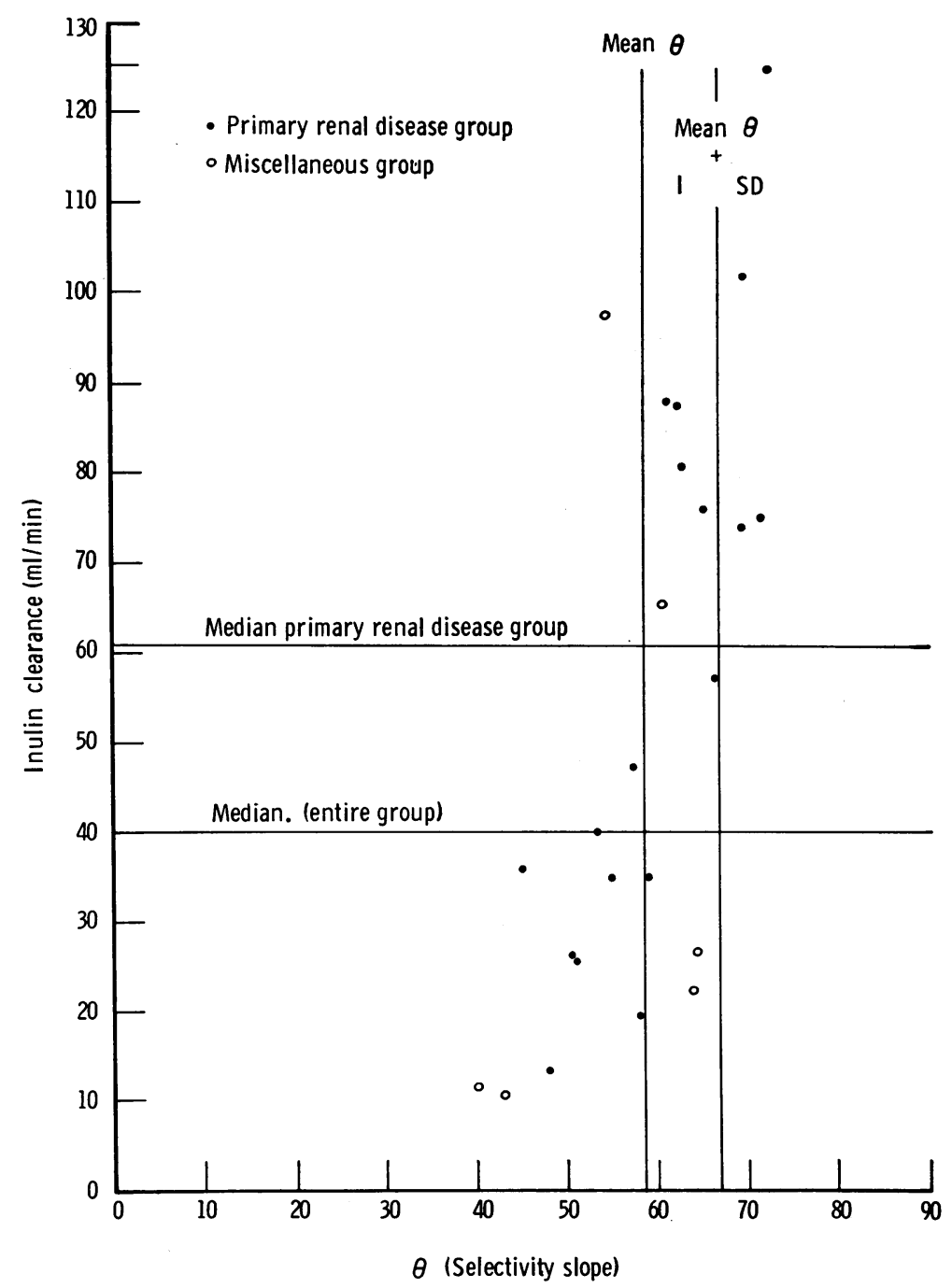

Fig. 6. CoMparison OF THE SELECTIVITY SLOPE WITH THE INULIN CLEARANCE.

is given in a scatter diagram (Figure 5). Renal biopsy, however, samples only a small per cent of the total nephron population and may not be representative.

Comparison of selectivity type with renal function. Inulin and para-aminohippuric (PAH) clearances were performed in 23 patients. An additional patient had only an inulin clearance. All procedures were carried out at the time selectivity slopes were determined. Fourteen patients had clearances determined before steroid therapy, and three in the initial stage of their disease, after which no steroids were given. Among the remaining seven patients, clearances were performed some time after an unsuccessful course of therapy had been instituted in four, or after their disease had long been established in three.

Data obtained from clearance studies were compared with selectivity slopes in individual patients to test whether there was significant correlation between near normal inulin and $\mathrm{PAH}$ clearances and a high selectivity type of proteinuria.

The median inulin clearance was $40 \mathrm{ml}$ per minute for the entire group and $61 \mathrm{ml}$ per minute for those with primary renal disease. Correlation was highly significant between the inulin clearance and the selectivity slope within both the primary renal disease group $\left(r_{16}=+0.83, p<0.001\right)$ and the entire group $\left(r_{22}=+0.66, p<0.001\right)$ (Figure 6). 
The median $\mathrm{PAH}$ clearance was $319 \mathrm{ml}$ per minute for the entire group and $343 \mathrm{ml}$ per minute for those with primary renal disease. Significant or borderline significant correlations existed between the $\mathrm{PAH}$ clearance and the selectivity slope for each group $\left(r_{21}=+0.34,0.1>\right.$ $\mathrm{p}>0.05$, and $r_{1+}=+0.54,0.05>p>0.02$, respectively).

The values for blood urea nitrogen (BUN), recorded at the time of initial observation, were correlated with selectivity slopes in 44 patients. For the entire group the correlation between the initial $\mathrm{BUN}$ and the selectivity slope was highly significant $\left(\mathrm{r}_{42}=-0.57, \mathrm{p}<0.001\right)$. In addition, a significant correlation existed within the primary renal disease group $\left(r_{22}=-0.63,0.01\right.$ $>\mathrm{p}>0.001)$.

Four patients in the primary renal disease group had inulin clearances above the median and had high selectivity types of proteinuria. All had a grade 3 or better response to steroid therapy. Four other patients who did not respond to therapy had inulin clearances above the median, but one had high selectivity slope (W. W.), and three had slopes equivalent to the average.

Of nine patients in the primary group with inulin clearances below the median $(61 \mathrm{ml}$ per minute), five had low and four average but below the mean selectivity types of proteinuria. In five patients there was no response to steroid therapy. In two patients, clearances were performed after an unsuccessful course of therapy, and in the remaining two patients no therapy was instituted.

In summary, those patients with a normal BUN and a near normal ( $75 \mathrm{ml}$ per minute or greater) inulin clearance can be expected to have a selectivity type of proteinuria that is at least equivalent to the average, but above the mean slope observed in this study $\left(58.6^{\circ}\right)$. Those patients who are azotemic, having grossly abnormal inulin clearances, invariably have selectivity slopes equivalent to the average but below the observed mean.

Comparison of selectivity type with duration of disease. Within the primary group, the duration of illness, estimated in months from the onset of symptoms to February 1964, was compared with respective selectivity slopes. Only slight correlation of borderline significance was found between the length of illness and the degree of selective protein excretion $\left(r_{23}=-0.35,0.05<p<0.1\right)$.

\section{Discussion}

The applicability of the method employed in this study is based on the following assumptions. a) When proteinuria exists, tubular reabsorption of protein, if any, must be nonselective (1). Studies by Hardwicke and Soothill (3) and Gregoire, Malmendier, and Lambert (20) support this thesis. $b$ ) The urine proteins measured are plasma-derived constituents, and protein components have not been added in any appreciable amount through tubular epithelium. Urinary albumin has been found to be identical with serum albumin $(21,22)$, and this is probably true of other urinary proteins (23) in the nephrotic syndrome. c) Although the antisera used are impure, the precipitin lines obtained in this method reflect the total amount of the specific protein in question. d) Spiro's observations of "pores" or "breaks" in the basement membrane (24) have not been confirmed by others $(25,26)$; nevertheless, structural defects of variable dimensions must be present to explain differential proteinuria in terms of molecular size. $e$ ) Although the logarithm of the molecular weight of a protein does not unvaryingly correspond to its molecular size, a direct proportion apparently exists for spherical molecules, with which we are concerned here (27). This relationship between clearance and molecular weight may be summarized by the equation, $\mathrm{dC} / \mathrm{dS}=-\mathrm{K}(\mathrm{C})$, where $\mathrm{C}$ is the relative clearance, $\mathrm{S}$ is the size or logarithm of the molecular weight of a protein, and $\mathrm{K}$ is the fractional decrease in relative clearance per change in unit size.

The results indicate a relationship between the initial responsiveness to steroid therapy and the degree of selective proteinuria that may be manifested by patients with the nephrotic syndrome.

Determination of the initial BUN and inulin clearance may give a preliminary indication of the selectivity pattern; however, alone it would not serve as a guide to steroid therapy. In one situation, where the patient is initially azotemic and has an abnormal inulin clearance, his selectivity slope can be expected to be average but below the observed mean in this study, and response to therapy 
is unlikely. If the initial $\mathrm{BUN}$ is normal and the inulin clearance is near normal, the selectivity slope can be expected to be at least average but above the mean. In this situation it is impossible to estimate with any degree of accuracy how the patient will respond. A more reliable prediction can be made from the selectivity slope.

Some caution should be taken with regard to the interpretation of the BUN and inulin clearance. It has been observed in children (28) and young adults (29) that the glomerular filtration rate is frequently reduced and the BUN elevated in the initial stages of the nephrotic syndrome, particularly in edematous states. These values returned to normal when diuresis occurred (30) after steroid therapy. Although an adult patient who responds favorably to steroid therapy might be expected to improve his inulin clearance, four patients in this study who did respond had a significantly higher inulin clearance at the initial observation than nine who did not respond.

In assessing indications for steroid therapy in adult patients with the nephrotic syndrome, attention is paid most often to the findings observed on renal biopsy. There is growing acceptance that those patients with nil disease respond best to steroids. Vernier, Farquhar, Brunson, and Good (31) reported that clinical and laboratory evidence of "recovery" from the nephrotic syndrome occurred only in children who showed on biopsy minimal glomerular changes. Johnson and Reader (32), however, reported two patients who had normal renal histology before treatment, but one remained edematous and a repeat renal biopsy revealed normal histology, whereas the other died 15 months after the onset of therapy.

From the results obtained in this study, evidently adults with the nephrotic syndrome may display a high degree of selective protein excretion despite significant glomerular pathology, and, a priori, respond to therapy. This implies that the glomerular "defect" in terms of "pore size," is not related to the glomerular alterations seen on renal biopsy. In some respects this would substantiate Vernier's view that there is no relationship between the width of the basement membrane and the extent of proteinuria (33). In addition, the selectivity pattern was observed to remain fairly constant in the steroid-responsive patient.
This may indicate that the "defect" persists despite increasing glomerular impermeability as evidenced by decreasing protein excretion. Studies in a larger group of patients are required to determine whether the selectivity pattern does remain constant during decreasing proteinuria. If this is true, it would imply that the effect of steroid therapy on reducing proteinuria is exerted by a mechanism other than changing "pore size."

Several investigators have utilized other methods of expressing glomerular permeability. By means of a microtechnique for paper electrophoresis, Wolvius and Verschure (34) determined the clearance ratio of total globulins to albumin. They found no correlation between this clearance ratio and the severity of the renal disorder or the amount of protein excreted. McCrory, Rapoport, and Fleischer (35) compared the ratio of albumin clearance to creatinine clearance in a group of nephrotic children. They found that complete remission following steroid administration occurred in those with the lowest $\mathrm{C}_{\mathrm{Alb}} / \mathrm{C}_{\text {Creatinine }}$ ratios. Lauson and associates (36) noted a striking decrease in the ratio $\mathrm{C}_{\mathrm{Alb}} / \mathrm{C}_{\text {Inulin }}$ in those children with the nephrotic syndrome who had favorable responses to ACTH therapy. Schreiner (37) noted a relationship between a permeability factor, $\mathrm{C}_{\mathrm{Alb}} / \mathrm{C}_{\text {Creatinine, }}$ and the level of serum cholesterol. Those patients with higher serum cholesterol appeared to have a greater clearance of albumin. Heymann, Gilkey, and Lewis (38) noted increased amounts of globulin in the urine of nephrotic children in whom the renal lesion progressed to glomerular fibrosis and atrophy, whereas Broch and Brodwall (39) reported that electrophoresis of the urine did not appear to yield any information regarding prognosis in patients with proteinuria, except those with myelomatosis.

\section{Summary}

With a gel diffusion precipitin technique and commercially prepared antisera, urine/plasma ratios of specific proteins were determined. Individual protein clearances, expressed as a percentage of transferrin clearance, were plotted as ordinates against respective molecular weights on a $\log$-log graph. A straight line was evident graphically, its constants were estimated by the method of least squares, and the slope, expressed 
as $\theta$, was determined. The slope of the line may be saicl to express the degree of glomerular selectivity to protein excretion. Sixty-five determinations were performed in 48 patients, 45 satisfying the usual criteria of the nephrotic syndrome.

1) Those patients with primary renal disease and the nephrotic syndrome who displayed high selectivity types of proteinuria ( $\theta$ greater than the average for the group $+1 \mathrm{SD}$ ) usually respond initially to steroid therapy, regardless of the acute or subacute glomerular changes observed on renal biopsy.

2) Those patients with chronic renal disease and the nephrotic syndrome display an average and frequently a low selectivity type of proteinuria.

3) There appears to be no characteristic type of selectivity for a given pathologic group of patients with the nephrotic syndrome.

4) The degree of selective protein excretion is not related to the total daily amount of protein being excreted at any one time and remains fairly constant despite fluctuation in the amount of protein being excreted.

5) There is a slight correlation of borderline significance between the degree of selective protein excretion and the duration of the disease, and the initial para-aminohippuric acid clearance.

6) A statistically significant correlation exists between the initial blood urea nitrogen or inulin clearance and the selectivity type of protein excretion. Those patients who were not azotemic and had initially near-normal inulin clearances had an average selectivity type or better.

7) It is suggested that if the adult patient is initially azotemic and has a grossiy abnormal inulin clearance. response to therapy is unlikely, whereas if the blood urea nitrogen is normal and the inulin clearance is near normal, response to therapy cannot be predicted with any degree of accuracy. Further studies of adult patients with the nephrotic syndrome are required to substantiate this premise.

\section{Acknowledgments}

We express our appreciation to Miss M. J. Newton, Miss J. Stubenbord, and Miss Dorothy Memolo for their technical assistance.

\section{References}

1. Hardwicke, J., and J. R. Squire. The relationship between plasma albumin concentration and protein excretion in patients with proteinuria. Clin. Sci. 1955, 14, 509.

2. Rowe, D. S. The molecular weights of the proteins of normal and nephrotic sera and nephrotic urine, and a comparison of selective ultrafiltrates of serum proteins with urine proteins. Biochem. J. 1957, 67, 435.

3. Hardwicke, J., and J. F. Soothill. Glomerular damage in terms of "pore size" in Renal Biopsy, a Ciba Foundation Symposium, G. E. W. Wolstenholme and M. P. Cameron, Eds. Boston, Little, Brown, 1961, p. 32.

4. Pappenheimer, J. R. Passage of molecules through capillary walls. Physiol. Rev. 1953, 33, 387.

5. Brewer, D. B. Renal clearances of dextrans of varying molecular weights. Proc. roy. Soc. Med. 1951, 44, 561.

6. Wallenius, G. Renal clearance of dextran as a measure of glomerular permeability. Acta Soc. Med. upsalien. 1954, 59 (suppl. 4).

7. Blainey, J. D., D. B. Brewer, J. H. Hardwicke, and J. F. Soothill. The nephrotic syndrome. Diagnosis by renal biopsy and biochemical and immunological analyses related to the response to steroid therapy. Quart. J. Med. 1960, 29, 235.

8. Berman, L. B., and G. E. Schreiner. Clinical and histologic spectrum of the nephrotic syndrome. Amer. J. Med. 1958, 24, 249.

9. Soothill, J. F. Estimation of eight serum proteins by a gel diffusion precipitin technique. J. Lab. clin. Med. 1962, 59, 859.

10. Schultze, H. E., and G. Schwick. Quantitative immunologische Bestimmung von Plasmaproteinen. Clin. chim. Acta 1959, 4, 15

11. Lou, K. Personal communication.

12. Schultze, H. E. Über Glykoproteine. Dtsch. med. Wschr. 1958, 83, 1742.

13. Kekwick, R. A., L. Vallet, M. Cutbush, P. L. Mollison, A. R. Thomas, P. G. H. Gell, and J. F. Soothill. Estimation of gamma globulin in the serum of patients with hypogammaglobulinaemia. J. clin. Path. 1961, 14, 470.

14. Squire, J. R., J. Hardwicke, and J. F. Soothill. Proteinuria in Renal Disease, D. A. K. Black, Ed. Philadelphia, F. A. Davis, 1962, p. 213.

15. Hawk, P. B., B. L. Oser, and W. H. Summerson. Practical Physiological Chemistry, 13th ed. New York, McGraw-Hill, 1954, p. 927.

16. Walser, M., D. G. Davidson, and J. Orloff. The renal clearance of alkali-stable inulin. $\mathrm{J}$. clin. Invest. 1955, 34, 1520.

17. Smith, H. W., N. Finkelstein, L. Aliminosa, B. Crawford, and M. Graber. The renal clearances of substituted hippuric acid derivatives and other aromatic acids in dog and man. J. clin. Invest. 1945, 24, 388.

18. Patte, J. C., G. Baldassaire, and J. Loret. Etude immuno-électrophorétique des protéinuries normales et pathologiques. Rev. franç. Etud. clin. biol. 1958, 3, 960. 
19. Berggård, I. The plasma proteins in normal urine. Nature (Lond.) 1960, 187, 776.

20. Gregoire, F., C. Malmendier, and P. P. Lambert. The mechanism of proteinuria, and a study of the effects of hormonal therapy in the nephrotic syndrome. Amer. J. Med. 1958, 25, 516.

21. Spector, W. G. Labelled glycine in the nephrotic syndrome. Clin. Sci. 1954, 13, 1.

22. Gitlin, D., and C. Janeway. An immunochemical study of the albumins of serum, urine, ascitic fluid, and edema fluid in the nephrotic syndrome. J. clin. Invest. 1952, 31, 223.

23. King, J. S., and W. H. Boyce. High Molecular Weight Substances in Human Urine. Springfield, I11., Charles C Thomas, 1963, p. 39.

24. Spiro, D. The structural basis of proteinuria in man. Electron microscopic studies of renal biopsy specimens from patients with lipid nephrosis, amyloidosis, and subacute and chronic glomerulonephritis. Amer. J. Path. 1959, 35, 47.

25. Farquhar, M. G. Electron microscopic studies on the renal glomerulus in the nephrotic syndrome in Edema, Mechanisms and Management, A Hahnemann Symposium on Salt and Water Retention, J. H. Moyer and M. Fuchs, Eds. Philadelphia, W. B. Saunders, 1960, p. 497.

26. Fiashi, E., G. Andres, F. Giacomelli, and R. Naccarato. Renal histopathology in the para-nephritic nephrotic syndrome; optical and electron microscopic studies of kidney biopsies. Sci. med. ital. (Eng. ed.) 1959, 7, 639.

27. Sobotka, H. Monomolecular layers: their application in physiology and medicine in Medical Physics, O. Glasser, Ed. Chicago, Year Book Publishers, 1955, vol. 1, p. 777.

28. Bruck, E., M. Rapoport, and M. I. Rubin. Renal functions in the course of the nephrotic syndrome in children. J. clin. Invest. 1954, 33, 699.

29. Folli, G., V. E. Pollak, R. T. W. Reid, C. L. Pirani, and R. M. Kark. Electronmicroscopic studies of reversible glomerular lesions in the adult nephrotic syndrome. Ann. intern. Med. 1958, 49, 775.

30. Holland, W. W., J. R. Colley, and K. A. M. Moore. The nephrotic syndrome in children treated with a course of prednisolone. Brit. med. J. 1958, 2, 479.

31. Vernier, R. L., M. G. Farquhar, J. G. Brunson, and R. A. Good. Chronic renal disease in children. Correlation of clinical findings with morphological characteristics seen by light and electron microscopy. Amer. J. Dis. Child., 1958, 96, 306.

32. Johnson, J. R., and R. Reader. Prognosis in the nephrotic syndrome. A study with particular reference to the adult and older child. Aust. Ann. Med. 1959, 8, 200.

33. Vernier, R. L. Discussion in Renal Biopsy, a Ciba Foundation Symposium, G. E. Wolstenholme and M. Cameron, Eds. Boston, Little, Brown, 1961, p. 47.

34. Wolvius, D., and J. C. M. Verschure. The diagnostic value of the protein excretion pattern in various types of proteinuria. J. clin. Path. 1957, 10, 80.

35. McCrory, W. W., M. Rapoport, and D. S. Fleischer. Estimation of severity of the nephrotic syndrome in childhood as a guide to therapy and prognosis. Pediatrics 1959, 23, 861.

36. Lauson, H. D., C. W. Forman, H. McNamara, G. Mattar, and H. L. Barnett. The effect of corticotropin (ACTH) on glomerular permeability to albumin in children with the nephrotic syndrome. J. clin. Invest. 1954, 33, 657.

37. Schreiner, G. E. The glomerular membrane in the nephrotic syndrome in Edema, Mechanisms and Management, A Hahnemann Symposium on Salt and Water Retention, J. H. Moyer and M. Fuchs, Eds. Philadelphia, W. B. Saunders, 1960, p. 485.

38. Heymann, W., C. Gilkey, and M. Lewis. The prognostic significance of globulinuria in the nephrotic syndrome. Amer. J. Dis. Child. 1956, 91, 570.

39. Broch, O. J., and E. Brodwall. Urinary proteins in renal diseases. Acta med. scand. 1958, 160, 353. 